\title{
DIFICULDADES NA COMPETÊNCIA ORAL DE ESTUDANTES DE EDUCAÇÃO SECUNDÁRIA NUMA SOCIEDADE BILINGUE COM DUAS LÍNGUAS EM CONTATO: O CASO DO ENSINO DE INGLÊS PARA FALANTES DE CATALÃO E ESPANHOL
}

\author{
DIFICULTADES EN LA COMPETENCIA ORAL DE ESTUDIANTES DE \\ EDUCACIÓN SECUNDARIA EN UNA SOCIEDAD BILINGÜE CON DOS \\ LENGUAS EN CONTACTO: EL CASO DE LA ENSEÑANZA DE INGLÉS A \\ HABLANTES DE CATALÁN Y ESPAÑOL
}

\author{
ORAL COMPETENCE DIFFICULTIES IN SECONDARY EDUCATION \\ STUDENTS WITHIN A BILINGUAL SOCIETY WITH TWO LANGUAGES IN \\ CONTACT: THE CASE OF ENGLISH TEACHING TO CATALAN AND SPANISH \\ SPEAKERS
}

\author{
Celia GUTIÉRREZ VILLAR ${ }^{1}$
}

RESUMO: Aprender uma segunda língua é considerado como algo positivo ou estimulante por muitas pessoas. Dada a sua importância ou valor, a maioria dos cidadãos sabe mais do que uma língua. $\mathrm{O}$ objetivo deste estudo é mostrar como o inglês é adquirido numa sociedade onde existe um contato linguístico (catalão e espanhol), focalizando particularmente o tipo de comunicação e interação presente no sistema educacional. O nosso principal objetivo é decifrar as atitudes que os alunos têm em relação a esse tema e indicar os modos em relação a como eles usam a linguagem, para poder mencionar os maiores obstáculos que enfrentam no processo de aquisição. Além disso, tentará indicar quais são os aspectos mais relevantes a serem considerados no desenvolvimento da comunicação oral dentro das salas de aula.

PALAVRAS-CHAVE: Línguas em contato. Competência oral. Aquisição de segundas línguas. Interação. Feedback.

RESUMEN: Aprender una segunda lengua es considerado como algo positivo o estimulante por muchas personas. Dada es su importancia y valor que gran parte de los ciudadanos saben más de una lengua. El propósito de este estudio consiste en mostrar cómo el inglés se adquiere en una sociedad donde existe un contacto lingüístico entre el catalán y el español, centrándose, en concreto, en el tipo de comunicación e interacción presente en el sistema educativo. Su objetivo principal es descifrar las actitudes que los estudiantes tienen en relación a este tema e indicar las formas en que ellos utilizan el lenguaje, para así poder mencionar los mayores obstáculos a los que se enfrentan en el proceso de adquisición del mismo. Además, se intentará señalar cuáles son los aspectos más relevantes a tener en cuenta a la hora de desarrollar la comunicación oral dentro de las aulas.

${ }^{1}$ Generalitat de Catalunya, España - Profesora de educación Secundaria Obligatoria. INS Montsià. Terres de l'Ebre. ORCID: https://orcid.org/0000-0002-3521-6659. E-mail: cgutierrezvillar@gmail.com 
PALABRAS CLAVE: Lenguas en contacto. Competencia oral. Adquisición de segundas lenguas. Interacción. Retroalimentación

ABSTRACT: Learning additional languages is considered to be something positive and stimulating for a lot of people. Such is its significance or value that almost every citizen knows more than one language. The purpose of this study relies on showing how English language is acquired in a society where there is a language contact between Catalan language and Spanish language, focusing particularly on the kind of communication and interaction within the educational system. Its main objective is to find out the attitudes learners have towards this topic and indicate the ways in which they make use of the language, so as to mention the major obstacles they may face in the acquisition process. Additionally, it tries to highlight which are the most relevant aspects to carefully bear in mind when developing oral communication within the classrooms.

KEYWORDS: Language contact. Oral competence. Second language Acquisition. Interaction. Feedback.

\section{Introduction}

In recent years, there has been an increasing interest in the acquisition of second languages, especially English. When learning a new language, people are required to reach certain level in four different skills: writing, listening, reading and speaking. As for English as a second language, people should consider that there is no unique English but rather many different varieties, so depending on the type people study there will be different linguistic associations. For its part, Spain commonly offers students to learn the British variety, as it is normally considered more formal or correct, although in some occasions people prefer studying the American one.

Hence, the main purpose of the study is to find out a proper way to achieve oral competence. In broad terms, oral competence refers to the act of expressing or communicating some information considering the context, and the person the speaker is addressing to, being this exchange effective and productive. Additionally, it is one of the skills required when learning a language and it is widely used as it allows communication between people who speak that particular language. It is also used for informing about a topic or transmitting our knowledge of any subject. Thus, oral communication is required to fulfil some competences of the language and enables people to cover their necessities. 
Our main objective is to analyse, describe and reflect on how English is developed and studied through education, especially focussing on Secondary Education students within a peculiar background where we may find two languages in contact: Spanish and Catalan. In order to do so, there are several steps to be followed: an observation and participation in the lessons, some kind of discussions of the topic with both teachers and students which will enable our study to develop a proper analysis and comparison with what theory says, and finally a presentation of the issues in relation to a theoretical framework.

The reader should bear in mind that this is based on a small sample of interactions; considering also that the approaches explained here are related to a specific level of education, as well as a specific bilingual background, so some of the ideas may not be the case for other different cases.

\section{Hypothesis}

This research attempts to examine closely how both students and teachers communicate within lessons, trying therefore to answer questions such as how they perform in the classrooms, which languages they normally use, which methods they carry out and why they do so. In order to carry it out, several of groups of students from different levels have been observed. It should be taken into consideration that there are many possible activities within an English course, but it is beyond the scope of this study to examine them all. Hence, this research is just going to be focused on the ones performed in several high schools in Spain where students deal with three different languages: Spanish, Catalan and English.

One of the central concerns of this research is to classify the different oral activities depending on its type. Consequently, aspects as the presentation and the basic information of them will be commented. Additionally, this study aims to address questions related to the appropriateness of activities in order to improve the language, and check whether the required skills have been reached. As a consequence, some topics such as the significance of theory and practice, exposure or formability will be explored.

Another central issue the study takes into consideration is whether the students' level of English encourages or blocks them. And, finally, the last objective of this research will be to present several results and conclusions reached from the analysis of 
all the aspects detailed above. We will try to give a solution to all the questions stated in this part of the research considering reliable information.

\section{Theoretical framework}

It is well known that learning a second language involves being able to use it in a variety of ways, commonly known as writing, reading, listening and speaking. Each skill has its difficulties and techniques but, in order to be proficient in that language, the control of all them has to be acquired. Due to practical constraints, this paper cannot provide a comprehensive review of every single skill, but rather it is going to deal with the oral competence (speaking). The Oral Communication Competency Assessment Committee of Virginia (2006, p. 3) defines oral competence as "effective interpretation, composition and extemporaneous presentation of information, ideas, and values to a specific audience". McCroskey (1982, p. 2) defines oral competence as "the ability of an individual to demonstrate knowledge of the appropriate communicative behaviour in a given situation". For her part, Bagarić (2007, p. 95) defined communicative competence "not only as an inherent grammatical competence but also as the ability to use grammatical competence in a variety of communicative situations". Hence, the main characteristic of the term is effectiveness in communicating information taking into account both the situation and the person who is receiving this kind of data.

There are many types of English(es) around the world but the commonly studied is the Standard English. Jenkins (2009, p. 36) defines it as:

the variety of the language that students of English as a foreign language or second language are taught when receiving formal instruction. The term refers to grammar and vocabulary but not to pronunciation/spelling which may be a blend of American English + British English depending on the school or teacher.

In Spain, people generally study the British Standard, as they think it has a global reach, that is, it allows for universal intelligibility. The main basis for its acquisition at high schools depends normally on the goals of teaching communicative competence. Teachers want students to acquire an effective knowledge of the linguistic forms for the social purpose of the language. 


\section{Value and attitude towards oral competence}

In recent years, there has been an increasing amount of literature on the oral competence and the aspects it involves. The majority of the population considers oral skills necessary to learn a language properly and communicate effectively with people who share this target language. In the field of education, most people regard English as the best language to learn as it is worldwide spoken. This characteristic makes English to be taught as a second or additional language in formal schools of any kind.

\section{Listing of activities depending on its type}

The activities performed in the English lessons normally include different genres of oral communication, going from the more formal ones to the less formal or casual. The major differences between them are the relationship between the objects, people or ideas mentioned by the speaker. Brown and Yule's (1993, p. 109) classification has been considered in the following lines to make a division of the most relevant activities to be performed within the classrooms:

\section{a) Static relationships}

The kind of tasks included in this first group normally share the same point of view of the language use, as they often involve spatial relationships and the attribution of particular properties. The activities do not focus on achieving correct or perfect vocabulary but rather in satisfactory and adequate specifications which enable the hearer to recognize the aspects the speaker wants to transmit. Therefore, in this set we may include tasks as descriptions and instructions.

\section{b) Dynamic relationships}

These are normally active, progressive and changing activities. These intercommunicative tasks look for are establishing and maintaining social relations. They try to motivate students, and demand a student speaking and listening to one or some others. The amount of activities is wider than in the other types. The most common examples are: storytelling, problem-solving sessions, question-answers activities, and role-playing.

\section{c) Abstract relationships}


These mainly refer to activities focused on someone's ideas, beliefs or justifications, rather than on concrete objects. They are therefore subjective tasks where students have to clarify and support their postures. The most significant example is opinion-expressing.

\section{Factors that cause speaking difficulties to learners}

So as to continue with this research, it must be emphasised some of the main difficulties Spanish and Catalan speakers face when acquiring English. Consequently, some of the most repeated factors are related to linguistic difficulties, inhibition, mother tongue issues, or participation obstacles:

\section{a) Linguistic difficulties}

According to Jenkins' research (2009, p. 51), the main difficulties students face when learning English are related to phonology and grammar. In the first place, he mentions spelling difficulties, and he clarifies that they are due to the characteristic that English is not always pronounced in the same way as it is written. The major drawbacks are related to letters pronunciation, especially silent letters, stressed and unstressed vowels or diphthongs.

Regarding grammar, Jenkins (2009, p. 52) distinguishes three major reasons: the great amount of tenses, the ones which have simple and continuous forms; modal verbs and their difficulties related to form and function and, the most controversial one, the phrasal verbs with all their literal and metaphorical meanings and their rules.

\section{b) Low or uneven participation}

When trying to carry out interactive conversations some problems are typically observed and they affect both the teacher and the student roles. It is basically a lack of students' participation what makes the teacher unable to accomplish his purposes. In their investigation, Brown \& Yule (1993, p. 34) state that this fact is caused by the conditions under which the activity is based on. Therefore, students will have a higher participation in situations where they feel more comfortable or under less "communicative stress". Thus, they list three conditions which affect these situations: context, knowledge and type of task. The first one involves the relationship with the 
listener and the situation, being a familiar environment the most comfortable. Regarding knowledge, he mentions two aspects: language and information, and explains that the more the speaker knows, the more confidence and motivation he has. Finally, the two main aspects related to type of task are the amount of knowledge the student has about it and the understanding and organization of it. If students know the objectives of the task and have a clear idea of what they have to talk about, the result and participation will be better than if they are not aware of it.

\section{c) Mother tongue use}

Another striking concern is mother tongue usage. The most apparent problem is interference (negative transfer) from the first language to the second one when students do not know a word, saying therefore invented words, or making use of the commonly known "false friends". Krishna (2006, p. 81) remarks that mother tongue use is a natural act and if used correctly it can be a useful tool, but, using mother tongue continuously may lead students to reject their communicative skills and needs, and also to originate future problems related to communication outside the classroom.

\section{d) Inhibition}

This last aspect is in great part related to students' personality, as the more confident they are with their aptitudes, the better they will try to perform in English. It is commonly observed in English lessons how some students feel afraid of making mistakes, to be corrected by the teacher, or are unable to speak because of their shyness. As Scarcella (1990, p. 338) sees it, these personality aspects result in negative and inaccurate stereotypes, which make them feel incapable of performing a speech. Therefore, these difficulties interfere in their abilities, eliminate their objectives and make them judge themselves in a pessimistic way.

\section{Spoken production requirements: assessment and feedback}

Assessment basically depends on the person that evaluates students' skills having defined the requirements before. There are some basic notions that should always be taken into account when estimating students' speech.

It is commonly observed that when testing a language, both teachers and students just focus on the things explained and seen in class, that is, they set limits to the 
language. According to Jenkins (2009, p. 123) and Seargeant (2012, p. 70) this effect is called washback. This influences the way in which society sees the language because it makes them not care about the acquisition and the language itself, but rather focus on passing an exam or performing a right speech.

In the same way teachers should have different activities showing students' abilities and progress in order to determine their level. Students should also obtain some feedback from their teachers in all the tasks performed, so they can be aware of their advance or retreat in the language. Depending on how these comments are transmitted, they will have different receptions and reactions.

\section{Methodology}

With the aim of reaching an effective way to obtain a proper level in oral competence, a variety of explorations have been done. As to define which an adequate process to develop in a specific school (in this case, Ramón Muntaner High School) could be, a recompilation of data was needed. It was examined how the components of the lessons dealt with this skill, and the most significant factors for the study were its usage, attitude, problems and evaluation. Classrooms were comprised of an average of 25 to 30 students, including boys and girls, speakers of both, Spanish and Catalan language, grade repeaters and the like. Therefore, diversity was clearly observed within the classrooms. A variety of activities were developed and examined, focusing precisely on aspects such as correctness, fluency or mother tongue use.

As said before, due to practical constraints, this study does not focus on all kinds of attitudes, activities or linguistic features, but rather in those which were considered more relevant for the research's purpose and those observed in a specific school. Hence, readers should consider that this analysis may not be the case for other different ones.

\section{Students approaches to the language}

In recent years, there has been a significant interest in learning additional languages to people's mother tongue. In Spain, English is compulsory during the educational period of students. In addition, there are many other ways of acquiring the language outside schools or high schools. Availability of contact is therefore possible if the person in charge of learning the language really wants to progress. 
One of the most significant problems is that English modules are devoted to instructional features, that is to say, it is only useful for class activities and it is not really connected to real life. In addition, students mention that the amount of time devoted to oral communication is lower than they would like it to be, so exposure is insufficient for them. Still, students acknowledge that learning English is important for their future life. In the majority of the cases, students view English as decisive for future jobs, necessary to travel to other countries and essential to communicate with people from other countries. On the other hand, there are others who do not agree with theses points of view and think English is boring, useless, and needless, and in many cases, they blame instruction as the cause of these thoughts.

\section{Analysis of the activities observed}

It was observed how some of the above-mentioned activities were performed in this high school but, were they carried out as they should be according to theory? Did they achieve their goals? Were the materials, contexts and requirements the appropriate ones?

\section{a) Static relationships}

The only tasks observed were descriptions or either pictures or themselves. Regarding the materials for both examples, teachers did not do much, as they could be just taken from a book and the personal descriptions need nothing but an example. Clarifications were short and simple, and according to the teachers they were easy and not complicated tasks, so they took for granted that students knew what and how they should do them. However, though they gave one example for each task, the requirements were not specified, so some students were not too sure of which language they should use, how long it should be, etc.

Not everything was negative but there were some positive perspectives. In some cases, teachers gave learners some feedback, but the way they did it was not really appropriate. The advanced ones only received compliments. However, the rest were only told the mistakes they made, the aspects they should improve, but hardly ever did they get a positive comment. However, the most highlighting aspect was the tone in which these issues were reported, which for the first ones was a sweet, fragile voice and for the others an upset and tactless speech. 


\section{b) Dynamic relationships}

The most common task was question-answer activities. They were always related to reading comprehension, and occasionally, to pictures. The significant problem was that interest was not in fluency but rather in accuracy, in giving the right answer to a closed-question. However, teachers should have presented open-questions, so students would have been able to focus on fluency and freely answer according to their perspectives.

Secondly, problem-solving sessions were practised. In contrast to the previous ones, these tasks were performed in isolation, and they lasted a whole session. They were commonly related to aspects seen in class, a fact that was seen both as an advantage and disadvantage, because depending on their knowledge of the topic they just prepared and memorized them, or tried to improvise. The most significant aspects were that as they commonly had little time to prepare their speeches and they did them in pairs or threes, participation, cooperation and partnership were higher, so less inhibition was observed. The context was relaxed and they perceived the task as a game rather than as a test.

Regarding dialogues we appreciated how they were somewhat force. Nevertheless, they were good ideas to learn or practice grammar in a different way. The problem was that, as they did not always allow students to improvise or give their opinions, they were sometimes thought to be useless tasks. In addition, no feedback was given to them.

The last task observed within this type of activities was storytelling. The proceeding of these activities took whole sessions. The topics were not usually related to the contents of the units, so they commonly lost a lot of time looking up for or they said lots of words and expressions in Spanish/Catalan. However, they were able to use the language they considered appropriate, so no fixed expressions or compulsory use of specific grammar was required. This created a comfortable environment and fluent speeches. But, once again, feedback was not given to students, so what seemed to be working did not have a proper closing. 


\section{c) Abstract relationships}

This last type was not really observed in any lesson. Teachers' comments about the avoidance of these activities commonly were related to lack of time, problems they may cause due to misunderstandings, etc.

\section{Learners' obstacles}

\section{a) Linguistic difficulties}

With regard to this first type of difficulties, many students acknowledge having lack of proficiency in several fields such as pragmatics, lexis and pronunciation. Due to this, transfer from the native language (L1) to the second one (L2) occurs, in the majority of the cases causing negative transfer or interference.

Students also mention the importance of the treatment of error at this point. There are several ways of correcting mistakes which involve different reactions in students. It will depend on the context and the personality of both teacher and student to choose the appropriate one. It is essential for students to know how they perform their speeches and how their evolution is.

\section{b) Low or uneven participation}

One of the major obstacles when performing oral activities is participation, as it is not as high as teachers would like it to be. The most significant reason for the lack of participation is absence of clarifications of the aims or objectives of the activities being performed. At this point, examples are essential as they show how the activity should be performed in a proper way.

\section{c) Mother tongue use}

Translation into the mother tongue is always an easy tool to make students understand what the teacher is trying to explain, but is it positive to use it all the time? Surveys done to students reflect that they perceive translation as a necessary tool in English lessons, but they are really conscious that a high level of translation deals to lower levels of acquisition.

\section{d) Inhibition}


The last common feature regarding students' difficulties with oral skills is inhibition. When asked, most of them claimed that personal characteristics like shyness, nervousness and anxiety are the reason of their lack of both participation and improvement. The stated features depend on the situation or context, and how interaction and instruction develop throughout the course, but they also account for students' emotions and feelings every single day.

\section{Evaluation requirements}

When performing an oral activity, teachers should first clarify the objectives and also its requirements. However, when this is not done, students memorize their speeches, they learn expressions and lists of vocabulary by heart and then they just mention them in their speeches with the objective of sounding good, and passing the activity.

On the one hand, it has been observed how teachers tend not to assess oral competence, or if they do so, it represents a small percentage of the global mark. From the experienced had in Ramón Muntaner High School, teachers do not usually perform oral exams or tests, but rather they develop varied activities in class, and they take notes of some of them, the ones they consider appropriate. This affects higher levels, being the lower ones left aside, as they are not considered to have a proper level to perform an oral speech. So, the first mistake they are making is establishing a selection of who can or cannot be able to make a speech without giving them the chance to try.

It was also observed that although teachers in some of the activities say they will assess specific characteristics of the speech such as content, they end up focusing on just correctness, so what they do is a kind of error analysis, where they look for students' mistakes but they do not evaluate the good aspects of the performance.

Last but not least, there is a final issue: feedback. Teachers know about its importance but, why do not they give it to students? Surveys report that students do not usually get feedback from their tasks, no matter the skill they refer to. Leaving aside the explanation of these characteristics is devaluing the activities themselves, as if there are no comments on them, students do not really care if they do the speaking task in a right or wrong way, as they think teachers neither do so.

Thus, when dealing with oral activities, teachers should bear in mind several aspects such as clarification of the task, the aims and requirements; the importance of 
practice and interaction in class; and feedback on the speech. Only when all these aspects have been met can they claim to have performed a proper oral task.

\section{Results}

One of the most common issues revealed during our analysis is lack of practice. We find that there is not enough development of oral activities, and in most cases, it is due to lack of and an overemphasis on course book concerns. But, is it really the main problem for oral communication?

Regarding interaction, the first aspect that comes to light is teachers' lack of participation or interaction within the oral activities. In addition, we may remark that the approach or attitude given to this kind of activities is unnatural, meaning that communication is not spontaneous.

Interestingly, this project has made me realize that although there are several ways of assessing students, as the moment of truth arrives, teachers regularly assess what they think is adequate for each student, that is, they may not focus on every single aspect in all students but rather estimate each one for his/her own skills: pronunciation, grammar, mistakes, creativity, risk-taking, etc. But, is this fair or adequate? It may, but it may not, as it may lead to what we mentioned in the previous section of focusing just on students' errors and leaving aside their strengths.

\section{Conclusions}

English spoken language is becoming more and more significant in every society for a variety of reasons and causing an interest in the learning of the language. However, in the learning process there are aspects that continue failing, since the outcomes people are pursuing are not actually attained.

Hence, we may now argue that the main problems have to do with exposure, interaction and evaluation, including both assessment and feedback. The evidence from this study suggests that it exists concern of the significance of English oral competence and certain desire to achieve a higher rank, but due to the aforementioned reasons the process sometimes changes its direction and students abandon or reject the language. It seems that inappropriate or insufficient exposure to the language, as a limited number of hours devoted to the process and a high use of the mother tongue is not enough to reach 
a proficient level in the language. In addition to this, lack of innovation and creativity in the activities and absence of real-life situations also lead to an uncomfortable environment, which does not benefit students' learning.

The study has also indicated that the kind of interaction that occurs in classrooms is not appropriate in all cases, particularly focusing on the teacher's one.

Regarding evaluation, we observed that even though oral communication is developed during the academic year, the importance given to it was inadequate as it did not really account for students' global mark; and despite being carried out it was not generally commented, so students did not get any feedback on their speeches.

\section{REFERENCES}

BAGARIĆ, V. Defining communicative competence. Metodika, v. 8, br. 1, p. 94-103, 2007. Available in: https://hrcak.srce.hr/file/42651. Accessed in: 25 abr. 2019.

BROWN, G.; YULE, G. Teaching the Spoken Language. Cambridge: Cambridge University Press, 1993.

JENKINS, J. World Englishes. A resource book for students. Abingdon: Routledge, 2009.

KRISHNA, B. Mother Tongue Use in English Classroom. Journal of NELTA, 2006. Available in:

https://www.academia.edu/962234/Mother_Tongue_Use_in_English_Classroom?auto= download. Accessed in: 25 abr. 2019.

MCCROSKEY, J. Communication competence and performance: a research and pedagogical perspective. Communication Education, v. 31, 1982. Accessed in: 25 abr. 2019

ORAL COMMUNICATION COMPETENCY ASSESSMENT COMMITTEE. A Report on Oral Communication at the University of Virginia. Virginia: University of Virginia, 2006.

SCARCELLA, R.; ANDERSEN, E.; AND KRASHEN, S. Developing communicative competence in a second language. Boston: Newbury House Publishers, 1990.

SEARGEANT, P. Exploring World Englishes: Language in a Global Context.

Abingdon: Routledge, 2012. 


\section{Cómo citar este artículo}

GUTIÉRREZ VILLAR, Celia. Oral competence difficulties in secondary education students within a bilingual society with two languages in contact: the case of English teaching to Catalan and Spanish speakers. Rev. EntreLínguas, Araraquara, v. 5, n. esp. 1, p. 297-311, jul., 2019. E-ISSN: 2447-3529. DOI: 10.29051/el.v5iesp.1.12983

Submetido em: 01/06/2019

Aprovado em: 30/06/2019

Publicado em: 01/10/2019 